\title{
KERAGAAN TIGA VARIETAS PADI ADAPTIF LAHAN RAWA LEBAK YANG DITANAM PADA UMUR BIBIT BERBEDA
}

\author{
(The Performance of Three Adaptive Varieties of Lebak Swamp Land Planted at \\ Different Seed Ages)
}

\author{
Hatna, M. Rizki Norfajerin, Lindawati dan Nurul Istiqomah \\ Prodi Studi Agroteknologi, Sekolah Tinggi Ilmu Pertanian Amuntai \\ Jl. Bihman Villa No 123 Amuntai Kalimantan Selatan 71417 Telp (0527)62202 \\ Penulis Koresponden : Hatnahameed@gmail.com
}

Article Submitted : 26-12-2021

Article Accepted : 17-01-2022

\begin{abstract}
Planting adaptive varieties is a necessary effort should to be taken so that production higher, resistant to pests and diseases. Seeds are an essential component of production technology to obtain optimal production levels. This study aims to determine (i) the best interaction, (ii) the best adaptive varieties (iii) the best seedling age. This research was conducted in Muara Tapus Village from March to September 2021. Using a factorial Randomized Block Design (RBD). The first treatment was varieties with three levels, namely Ciherang, Cisokan Putih, and Mekongga; the second treatment was seedling age with five levels, namely seedling age of 30, 25, 20, 15, and 10 days. The results showed that the best interaction resulted from the Cisokan Putih variety treatment with 30 days of seedling age. Cisokan Putih variety and seedling age of 30 days are the best adaptive varieties and seedling age.
\end{abstract}

Keywords: Seedling age, adaptive varieties and lebak

\section{PENDAHULUAN}

Di Indonesia luas lahan rawa lebak mencapai 34,12 juta hektar. Namun kontribusinya dalam produksi pangsa pangan nasional masih rendah, tidak sebanding dengan luas lahan rawa lebak. Dari luasan tersebut yang berpotensi untuk pengembangan pertanian sekitar $41 \%$ dari total luas lahan rawa. Namun demikian, luas lahan rawa yang telah dikembangkan masih rendah (Sulaiman et. al., 2018). Penerapan teknologi tepat guna dilahan rawa akan mampu menyelesaikan permasalahan pangan yang semakin besar, salah satunya melalui peningkatan kesejahteraan petani (Ar-Riza dan Rina, 2003).
Pengembangan lahan rawa lebak di masa depan cukup menjanjikan karena potensial dan prospektif lahannya. Lahan rawa memliki karakteristik lahan yang khas. Dengan $\mathrm{pH}$ yang berkisar 3,5 - 4,5 yang umumnya dipengaruhi oleh organik dan tingkat kedalaman pirit, oksidasi dan sifat kimia. Permasalahan yang sering terjadi dilahan rawa lebak adalah meningkatnya unsur $\mathrm{Al}, \mathrm{Fe}$, asam-asam organik dan diringi oleh kahat hara $\mathrm{P}, \mathrm{Cu}$ dan $\mathrm{Zn}$ (Hatta et. al., 2018). Dalam pengelolaannya lahan rawa membutuhkan perlakuan khusus dari segi penerapan tekonologi yang harus spesifik lokasi, pemilihan benih sampai ke tahap pascapanen (Herlinda, 2019). Fluktuasi genangan menjadi salah satu permasalahan 
yang cukup menantang untuk dihadapi dalam pengelolaan lahan lebak untuk pertanian. Selama ini telah dilakukan upaya diversifikasi pertanian dilahan rawa lebak namun hasil yang didapatkan masih belum optimal. Adapun penyebab belum optimalnya upaya diversifikasi ini dikarenakan kendala dari segi fisik dan kimia lahan, selain itu rendahnya hasil juga disebabkan oleh implementasi teknologi yang masih belum sesuai pada kondisi lokasi dan sosial serta budaya petani setempat. Selain itu petani juga tidak akan mengganti varietas yang dibudidayakan serta cenderung menggunakan varietas yang sama, kecuali varietas penggantinya memiliki tingkat pemasaran tinggi dan adaptif dilokasi mereka (Darsani, 2020).

Diperlukannya upaya yang ditempuh untuk meningkatkan produktivitas tanaman, resisten terhadap hama dan penyakit serta memiliki kualitas beras yang bagus. Salah satunya melalui pemilihan varietas yang adaptif pada lahan rawa lebak (Waluyo dan Suparwoto, 2019). Pemilihan komoditas yang dibudiyakan dan teknik budidaya menjadi penentu keberhasilan dalam pengembangan lahan rawa untuk pertanian. Komoditas dan teknik budidaya harus spesifik lokasi dan sesuai dengan sifat tanah pada lahan rawa tersebut (Sulaiman et. al., 2018). Berdasarkan data BPS HSU (2021) terjadi penurunan produksi padi di Kabupaten Hulu Sungai Utara selama beberapa tahun terakhir pada tahun. Pada tahun 2020 produksi padi mencapai 103.749 ton. Apabila dibandingkan dengan produksi padi tahun sebelumnya 143.403 ton, mengalami penurunan sebanyak 40 ribu ton atau sekitar $27 \%$ penurunan.

Fenomena umum yang terjadi pada mayoritas petani, bahwa sistem pembibitan pada lahan rawa lebak kurang menaruh perhatian pada penentuan umur bibit yang tepat untuk siap ditanam pindah (Porong, 2012). Sehingga perlu dilakukan pengkajian lebih mendalam tentang beberapa varietas padi yang adaptif serta penentuan umur tanam yang tepat untuk meningkatkan produksi padi.

Penentuan umur bibit dan sistem tanam pada budidaya padi diketahui dapat memberikan pengaruh yang lebih baik terhadap proses pertumbuhan dan produksi padi sawah. Namun kendati sistem tanam dan umur bibit yang tepat masih belum diketahui dengan pasti. Berdasarkan penelitian umur bibit 7 dan 14 mampu meningkatkan hasil gabah ton ha ${ }^{-1}$ jika dibandingkan dengan umur bibit 21 dan 28 hari. Komponen hasil tanaman ditentukan oleh komponen pada fase pertumbuhan (Anggraini et. al., 2013). Berdasarkan penelitian yang dilakukan Muyassir, (2012) umur bibit terbaik untuk ditanam pindahkan adalah 8 HSS mampu menghasilkan padi 8,01 ton ha $^{-1}$ sedangkan untuk umur 16 HSS hanya menghasilkan 7,66 ton ha1. Semakin lama bibit berada dalam fase pesemaian maka anakan yang dihasilkan akan semakin sedikit. Secara langsung jumlah anakan mempengaruhi hasil panen yang didapatkan. Anakan yang muncul sebelum umur tanaman mencapai 40 HSS akan mampu menghasilkan produksi gabah yang maksimal dengan kualitas yang baik. Namun sebaliknya anakan yang muncul setelah 40 HSS akan mengalami keterlambatan masa matang gabah serta kualitas gabah yang kurang baik (Muyassir, 2012).

\section{METODE PENELITIAN}

Penelitian ini merupakan penelitian dengan bentuk riset empirik yang menggunakan metode gabungan dalam pelaksanaannya yaitu secara online untuk mendapatkan data-data sekunder, penelitian laboratorium dan lapangan untuk mendapat data primer, serta digital untuk mengalisis data primer yang didapatkan.

\section{Tempat dan waktu}

Penelitian ini dilaksanakan di Desa Muara Tapus Kecamatan Amuntai Tengah dan dilaksanakan dari bulan Maret sampai Juni 2021. 


\section{Bahan dan alat}

Bahan dan alat yang diperlukan selama penelitian ini adalah lahan, 3 varietas padi, cangkul, parang, papan, paku, gergaji, neraca digital pestisida nabati, alat tulis, meteran, plang penelitian, ember, timbangan dan kamera

\section{Rancangan Percobaan}

Penelitian ini merupakan percobaan yang dilaksanakan dilapangan mengunakan Rancangan Acak Kelompok (RAK). Perlakuan yang diteliti adalah varietas padi (V) dan umur bibit (B). Perlakuan pertama adalah varietas padi (V) dengan tiga taraf yaitu : $\mathrm{v}_{1}=$ Ciherang, $\mathrm{v}_{2}=$ Cisokan Putih, dan $v_{3}=$ Mekongga. Perlakuan kedua adalah umur bibit (B) dengan lima taraf yaitu : $b_{1}=$ 10 hari, $b_{2}=15$ hari, $b_{3}=20$ hari, $b_{4}=25$ hari, dan $b_{5}=30$ hari. Terdapat 15 perlakuan dengan ulangan sebanyak 2 kali maka didapat 30 petak satuan percobaan.

\section{Peubah pengamatan}

Teknik pengumpulan data yang dilakukan adalah pengukuran variabelvariabel pengamatan dilapangan. Untuk variabel pengamatan tinggi tanaman $(14,21$, 28, 35 dan 42 HST), jumlah daun $(14,21$, 28,35 dan 42 HST), jumlah anakan $(21,28$, 35 dan 42 HST), umur muncul malai, anakan produktif, umur panen, panjang malai, banyak malai, biji per malai, berat basah, berat kering dan berat 100 biji.

\section{Analisis data}

Data yang didapat dari setiap perlakuan di analisis dan dilakukan uji kehomogenan ragam Bartlett, apabila homogeny maka selanjutnya di uji dengfan Uji F/ANOVA pada taraf 5\%. Setelah semua perhitungan ANOVA selesai, dilanjutkan dengan uji lanjutan untuk mengetahui perlakuan terbaik.

\section{HASIL DAN PEMBAHASAN}

\section{Interaksi varietas dengan umur bibit}

Berdasarkan hasil analisis ragam diketahui terdapat pengaruh nyata interaksi varietas dengan umur bibit pada tinggi tanaman 21 dan 42 HST dan jumlah anakan 28 hasil uji beda rata-rata disajikan pada Tabel 1 .

Tabel 1. Hasil uji beda rata-rata varietas padi dengan umur bibit terhadap tinggi tanaman padi (cm) umur 21 dan 42 HST dan jumlah anakan pada umur 28 HST

\begin{tabular}{|c|c|c|c|}
\hline \multirow{2}{*}{ Perlakuan } & \multicolumn{2}{|c|}{ Rata-rata tinggi tanaman $(\mathrm{cm})$} & \multirow{2}{*}{$\begin{array}{c}\text { Rata-rata Jumlah anakan (anakan) } \\
28 \text { HST }\end{array}$} \\
\hline & $21 \mathrm{HST}$ & $42 \mathrm{HST}$ & \\
\hline$\overline{v_{1} b_{1}}$ & $51,87^{\mathrm{efg}}$ & $86.185^{\mathrm{cd}}$ & $14.38^{\mathrm{abc}}$ \\
\hline $\mathrm{v}_{1} \mathrm{~b}_{2}$ & $51,12^{\text {efg }}$ & $83.185^{\mathrm{bcd}}$ & $11.13^{\mathrm{abc}}$ \\
\hline$v_{1} b 3$ & $39,12^{\text {abcde }}$ & $69.25^{\mathrm{ab}}$ & $9.50^{\mathrm{abc}}$ \\
\hline $\mathrm{v}_{1} \mathrm{~b}_{4}$ & $37,62^{\mathrm{abcd}}$ & $70.125^{\mathrm{abc}}$ & $8.88^{\mathrm{abcd}}$ \\
\hline $\mathrm{v}_{1} \mathrm{~b}_{5}$ & $34^{\mathrm{ab}}$ & $77.125^{\mathrm{abcd}}$ & $6.63^{\text {bcd }}$ \\
\hline $\mathrm{v}_{2} \mathrm{~b}_{1}$ & $56^{\mathrm{h}}$ & $99.31^{\mathrm{e}}$ & $14.00^{\mathrm{d}}$ \\
\hline$v_{2} b_{2}$ & $50,75^{\text {efg }}$ & $79^{\mathrm{abcd}}$ & $14.88^{\mathrm{d}}$ \\
\hline $\mathrm{v}_{2} \mathrm{~b}_{3}$ & $40,62^{\text {abcde }}$ & $88^{\mathrm{de}}$ & $12.00^{\mathrm{d}}$ \\
\hline $\mathrm{v}_{2} \mathrm{~b}_{4}$ & $41,62^{\text {bcde }}$ & $74.62^{\mathrm{abc}}$ & $9.25^{\mathrm{cd}}$ \\
\hline $\mathrm{v}_{2} \mathrm{~b}_{5}$ & $43^{\text {bcdef }}$ & $65.37^{\mathrm{ab}}$ & $9.38^{\mathrm{bcd}}$ \\
\hline $\mathrm{v}_{3} \mathrm{~b}_{1}$ & $46^{\text {cdefg }}$ & $80.37^{\text {bcd }}$ & $11.88^{\mathrm{bcd}}$ \\
\hline$v_{3} b_{2}$ & $54,87^{\mathrm{h}}$ & $84.25^{\mathrm{cd}}$ & $12.75^{\mathrm{bcd}}$ \\
\hline$v_{3} b_{3}$ & $51,37^{\mathrm{efg}}$ & $75^{\mathrm{abcd}}$ & $10.75^{\mathrm{abc}}$ \\
\hline $\mathrm{v}_{3} \mathrm{~b}_{4}$ & $42,12^{\text {bcdef }}$ & $75^{\text {abcd }}$ & $8.88^{\mathrm{ab}}$ \\
\hline $\mathrm{v}_{3} \mathrm{~b}_{5}$ & $33,12^{\mathrm{a}}$ & $63.25^{\mathrm{a}}$ & $6.50^{\mathrm{a}}$ \\
\hline
\end{tabular}

Keterangan : Nilai rata-rata yang dikuti huruf yang sama pada kolom yang sama menunjukan perlakuan tersebut tidak berbeda berdasarkan uji DMRT pada taraf $5 \%$. 
Tidak terdapat interaksi pada 14, 28, 35 HST, jumlah anakan pada 21, 35, 42 HST, jumlah daun pada 14, 21, 28, 35, 42 HST, umur muncul malai, anakan produktif, umur panen, banyak malai, panjang malai, biji per malai, berat basah, berat kering dan berat 100 biji padi.

Dari tabel diatas terlihat bahwa tinggi tanaman pada umur 21 HST menghasilkan tinggi tanaman tertinggi pada perlakuan $\mathrm{v}_{2} \mathrm{~b}_{1}$ (Cisokan Putih dengan umur bibit 30 hari) yaitu $56 \mathrm{~cm}$ berbeda dengan perlakuan lainnya. Pada umur 42 HST menghasilkan tinggi tanaman tertinggi pada $\mathrm{v}_{2} \mathrm{~b}_{1}$ (Cisokan Putih dengan umur bibit 30 hari) yaitu $99,31 \mathrm{~cm}$ tidak berbeda dari $\mathrm{v}_{2} \mathrm{~b}_{3}$ tetapi berbeda dengan perlakuan lainnya. Pada jumlah anakan 28 HST menghasilkan anakan terbanyak pada $\mathrm{v}_{2} \mathrm{~b}_{2}$ (Cisokan Putih dengan umur bibit 25 hari) yaitu 14,88 anakan tidak berbeda dengan $\mathrm{v}_{1} \mathrm{~b}_{4}, \mathrm{v}_{1} \mathrm{~b}_{5}$, $\mathrm{v}_{2} \mathrm{~b}_{1}, \mathrm{v}_{2} \mathrm{~b}_{2}, \mathrm{v}_{2} \mathrm{~b}_{3}, \mathrm{v}_{2} \mathrm{~b}_{4}, \mathrm{v}_{2} \mathrm{~b}_{5}, \mathrm{v}_{3} \mathrm{~b}_{1}$ dan $\mathrm{v}_{3} \mathrm{~b}_{2}$ tetapi berbeda dengan $\mathrm{v}_{1} \mathrm{~b}_{1}, \mathrm{v}_{1} \mathrm{~b}_{2}, \mathrm{v}_{1} \mathrm{~b}_{3}, \mathrm{v}_{3} \mathrm{~b}_{3}$, $\mathrm{v}_{3} \mathrm{~b}_{4}$ dan $\mathrm{v}_{4} \mathrm{~b}_{5}$.

Pada kondisi tergenang tanaman padi dapat tumbuh dengan baik. Akan tetapi kondisi genangan air yang berlebiha juga akan memberikan dampak negatif dan mempengaruhi kondisi tanaman padi terutama pada bagian hasil yang didapatkan pada saat panen. Tinggi genangan dan lama genangan secara essensial mempengaruhi pertumbuhan tanaman padi. Tinggi genangan $4 \mathrm{~cm}$ dan lama penggenangan 2 minggu menghasilkan pertumbuhan padi yang optimal dimana jumlah anakan yang dihasilkan lebih banyak (Rachmawati dan Retnaningrum, 2013). Umur bibit yang lebih tua mampu menghasilkan anakan yang lebih banyak disebabkan mampu beradaptasi dengan kondisi lahan yang tergenang cukup dalam.

Proses pembentukan anakan berlangsung kurang lebih 30 hari setelah tanam. Pada fase ini ada 2 tahapan yang penting yaitu pembentukan anakan aktif yang kemudian disusul dengan pemanjangan batang (Ihsan, 2012). Hal ini sejalan dengan hasil penelitian dimana terdapat pengaruh interaksi pada tinggi tanaman 21 HST dan jumlah anakan $28 \mathrm{HST}$, dimana pada umur 28 HST merupakan fase pembentukan anakan yang secara tidak langsung juga mempengaruhi tinggi tanaman. Pada umur 42 HST tidak menunjukan adanya pengaruh pada jumlah anakan dikarenakan sudah melewati fase pembentukan anakan dan hanya menunjukan adanya pengaruh pada tinggi tanaman dikarenakan pada 42 HST merupakan masih stadia perpanjangan batang. Hal ini sejalan dengan penelitian (Maulidiya, 2015) yang menyatakan bahwa batang mengalami perpanjangan yang pesat sampai 42 HST. Tinggi tanaman merupakan komponen yang memengaruhi hasil dikarenakan berkaitan dengan fotosintesis.

Menurut Guswara dan Samanullah, (2008) Varietas Cisokan menghasilkan tinggi tanaman tertinggi yaitu $102,28 \mathrm{~cm}$ dibanding Ciherang dan Mekongga 93,4 cm dan $94,2 \mathrm{~cm}$. Hal ini dikarenakan perbedaan pertumbuhan pada fase vegetatif lebih dipengaruhi oleh sifat genetik atau tergantung dari sensitifitas dari varietas yang dibudidayakan terhadap kondisi lingkungan. Hal yang sama Guswara dan Samanullah, (2008) nyatakan bahwa terciptanya keserasian antara lingkungan tanaman pada sistem budidaya intensif diduga mampu menjamin fungsi fisiologis yang lebih baik.

\section{Faktor tunggal varietas}

Hasil analisis ragam dan uji beda rata-rata varietas padi berpengaruh varietaas padi pada tinggi tanaman $21 \mathrm{HST}$, jumlah anakan 21 dan 28 HST, jumlah daun 14, 28 dan 42 HST, umur muncul malai, anakan produktif, berat basah, berat kering dan berat 100 biji padi. Namun tidak ada pengaruh varietas pada tinggi tanaman 14, 28, 35 dan 42 HST, jumlah anakan 28 dan 42 HST, jumlah daun 14, 21, 35 dan 42 HST, umur panen, banyak malai, panjang malai dan biji per malai. 
Tabel 2. Hasil uji beda rata-rata varietas padi terhadap tinggi tanaman 28 HST, jumlah daun 28 HST, jumlah anakan 21 dan 28 HST

\begin{tabular}{ccccc}
\hline \multirow{2}{*}{ Varietas } & $\begin{array}{c}\text { Tinggi tanaman } \\
\text { 21 HST }(\mathrm{cm})\end{array}$ & $\begin{array}{c}\text { Jumlah daun } \\
\text { 28 HST (helai) }\end{array}$ & $\begin{array}{c}\text { Jumlah anakan } \\
21 \text { HST (anakan) }\end{array}$ & $\begin{array}{c}\text { Jumlah anakan } \\
28 \text { HST (anakan) }\end{array}$ \\
\hline $\mathrm{v}_{1}$ & $42,75^{\mathrm{a}}$ & $70,30^{\mathrm{a}}$ & $7,33^{\mathrm{a}}$ & $10,10^{\mathrm{a}}$ \\
$\mathrm{v}_{2}$ & $46,40^{\mathrm{b}}$ & $81,78^{\mathrm{b}}$ & $9,25^{\mathrm{b}}$ & $11,90^{\mathrm{b}}$ \\
$\mathrm{v}_{3}$ & $45,50^{\mathrm{ab}}$ & $77,55^{\mathrm{a}}$ & $8,93^{\mathrm{a}}$ & $10,15^{\mathrm{a}}$ \\
\hline
\end{tabular}

Keterangan : Nilai rata-rata yang dikuti huruf yang sama pada kolom yang sama menunjukan perlakuan tersebut tidak berbeda berdasarkan uji DMRT pada taraf $5 \%$.

Keberhasilan pertumbuhan tanaman dipengaruhi oleh 2 faktor yaitu faktor genetik dan lingkungan. Faktor genetik berkaitan dengan pewarisan sifat/perilaku tanaman itu sendiri, faktor lingkungan berkaitan dengan tempat dimana tanaman itu tumbuh. Setiap varietas tanaman memiliki kemampuan yang berbeda dalam hal memanfaatkan sarana tumbuh dan kemampuan beradaptasi dengan lingkungan, yang mana hal ini akan mempengaruhi terhadap potensi tanaman (Anggraini et. al., 2013).

Pada Tabel 2 tinggi tanaman 21 HST perlakuan $\mathrm{v}_{2}$ (Cisokan Putih) menghasilkan tinggi tanaman tertinggi dibandingkan dengan perlakuan $\mathrm{v}_{1}$ (Ciherang) dan perlakuan $\mathrm{v}_{3}$ (Mekongga). Hal ini diduga karena Cisokan Putih lebih tahan terhadap cekaman lingkungan yang terendam air dibandingkan denganVarietas Ciherang dan Mekongga. Hal ini sejalan dengan penelitian Guswara dan Samanullah (2008) dimana Varietas Cisokan lebih unggul dari segi tinggi tanaman dibandingkan dengan Ciherang dan Mekongga.

Pada Tabel 2 jumlah anakan 21 dan 28 HST perlakuan $\mathrm{v}_{2}$ (Cisokan Putih) menghasilkan rata-rata jumlah anakan terbanyak pada dibandingkan dengan perlakuan $\mathrm{v}_{1}$ (Ciherang) dan perlakuan $\mathrm{v}_{3}$ (Mekongga). Perlakuan $\mathrm{v}_{1} \quad$ (Varietas Ciherang) dan perlakuan $\mathrm{v}_{3}$ (Mekongga) menghasilkan jumlah anakan yang tidak berbeda satu sama lain. Hal ini menunjukan bahwa 2 varietas ini memiliki rata-rata jumlah anakan yang hampir sama. Varietas
Ciherang merupakan hasil persilangan IR 64 dengan dengan beberapa galur IR lainnya dan Mekongga juga merupakan hasil persilangan IR 64 dengan padi jenis galur A2970 (Suprihatno et. al., 2009).

Pada Tabel 2, anakan produktif perlakuan $v_{2} \quad$ (Cisokan Putih) mampu menghasilkan jumlah anakan produktif terbanyak yaitu 14,9 anakan, sedangkan perlakuan $\mathrm{v}_{1}$ (Ciherang) menghasilkan 12,75 anakan dan $\mathrm{v}_{3}$ (Mekongga) menghasilkan 13 anakan. Jumlah anakan produktif lebih dipengaruhi oleh sifat genetik tanaman dimana berdasarkan deskripsi Cisokan memang mampu menghasilkan jumlah anakan sebanyak 20-25 anakan produktif, Ciherang menghasilkan 14-17 anakan produktif dan Mekongga menghasilkan 1316 anakan produktif. Varietas Ciherang merupakan hasil dari perkawinan silang dari IR 64 dengan dengan galur IR lainnya dan Mekongga juga merupakan hasil persilangan IR 64 dengan padi jenis galur A2970 (Suprihatno et. al., 2009). Varietas yang berbeda memiliki kemampuan berbeda dalam pembentukan jumlah anakan produktif. Hal ini disebabkan oleh sifat bawaab yang tedapat pada masing-masing varietas. Varietas Ciherang merupakan hasil persilangan IR 64 dengan dengan beberapa galur IR lainnya dan Mekongga juga merupakan hasil persilangan IR 64 dengan padi jenis galur A2970 Arrudeau dan Vergara, (1992) setiap varietas mempunyai kemampuan yang berbeda dalam menghasilkan anakan, hal ini disebabkan oleh faktor genetik yang dimiliki dari 
masing-masing varietas juga berbeda. Jumlah anakan produktif merupakan jumlah gambaran dari jumlah anakan yang dihasilkan sebelumnya.

Sari et. al., (2009) menyatakan setiap varietas padi mempunyai parameter umur berbunga dan umur panen yang berbedabeda terutama varietas yang dinyatakan toleran $\mathrm{Al}$ berdasarkan $\mathrm{RRG}$ dimana Mekongga memiliki umur berbunga dan umur panen lebih cepat dibandingkan varietas lain. Adapun perbedaan ini disebabkan oleh perbedaan karakter tanaman yang diuji sehingga menunjukan respon yang berbeda. Hal ini sesuai dengan hasil penelitiannya yang menunjukan bahwa Mekongga lebih cepat stadia vegetatif, umur berbunga dan umur panen. Hal ini sesuai dengan hasil penelitian Rahmawati (2002) bahwa perbedaan yang terjadi pada masingmasing varietas/genotif dan sifat ini merupakan sifat alami yang dimiliki masingmasing genotif yang terbentuk akibat dari adaptasinya terhadap lingkungan (toleransi terhadap lingkungan).

Tabel 3. Hasil uji beda rata-rata varietas padi terhadap umur muncul malai, anakan produktif, berat basah, berat kering dan berat 100 biji

\begin{tabular}{cccccc}
\hline Varietas & $\begin{array}{c}\text { Umur muncul } \\
\text { malai (HST) }\end{array}$ & $\begin{array}{c}\text { Anakan } \\
\text { produktif } \\
\text { (anakan } \\
\text { produktif) }\end{array}$ & Berat basah (g) & Berat kering (g) & $\begin{array}{c}\text { Berat 100 biji } \\
(\mathrm{g})\end{array}$ \\
\hline $\mathrm{v}_{1}$ & $58,83^{\mathrm{a}}$ & $12,75^{\mathrm{a}}$ & $37,40^{\mathrm{a}}$ & $30,53^{\mathrm{a}}$ & $2,09^{\mathrm{ab}}$ \\
$\mathrm{v}_{2}$ & $58,68^{\mathrm{a}}$ & $14,90^{\mathrm{b}}$ & $48,15^{\mathrm{b}}$ & $39,57^{\mathrm{b}}$ & $1,98^{\mathrm{a}}$ \\
$\mathrm{v}_{3}$ & $56,98^{\mathrm{b}}$ & $13^{\mathrm{a}}$ & $39,62^{\mathrm{a}}$ & $32,5^{\mathrm{a}}$ & $2,13^{\mathrm{b}}$ \\
\hline
\end{tabular}

Keterangan : Nilai rata-rata yang dikuti huruf yang sama pada kolom yang sama menunjukan perlakuan tersebut tidak berbeda berdasarkan uji DMRT pada taraf 5\%

Pada Tabel 3 berat basah dan berat kering perlakuan $\mathrm{v}_{2}$ (Cisokan Putih) menghasilkan berat basah dan kering terberat berbeda dengan $\mathrm{v}_{1}$ (Ciherang) dan $\mathrm{v}_{3}$ (Mekongga). Varietas berpengaruh nyata pada berat biji basah dan berat kering. Berat basah dan berat kering dipengaruhi oleh banyaknya anakan produktif yang dihasilkan. Pada anakan produktif perlakuan $\mathrm{v}_{2}$ (Cisokan Putih) mampu menghasilkan jumlah anakan produktif terbanyak sehingga juga menghasilkan berat basah dan berat kering terberat. Sifat genetik sangat berpengaruh pada jumlah anakan yang dihasilkan dimana berdasarkan deskripsi Cisokan memang mampu menghasilkan jumlah anakan sebanyak 20-25 anakan produktif, Ciherang menghasilkan 14-17 anakan produktif dan Mekongga menghasilkan 13-16 anakan produktif (Suprihatno et. al., 2009).
Pada Tabel 3, berat 100 biji padi terdapat pengaruh nyata varietas, perlakuan $\mathrm{v}_{3}$ (Mekongga) menghasilkan berat 100 biji terberat tidak berbeda dengan $\mathrm{v}_{1}$ (Ciherang) dan $v_{2}$ (Cisokan Putih) menghasilkan berat 100 biji paling ringan. Berat 100 biji lebih dipengaruhi oleh sifat genetik dari varietas. Berdasarkan deskripsi varietas 1000 biji padi Ciherang dan Mekongga mampu menghasilkan berat $26 \mathrm{~g}$, sedangkan untuk Cisokan hanya $22 \mathrm{~g}$ (Suprihatno et. al., 2009).

\section{Faktor tunggal umur bibit}

Berdasarkan hasil analisis ragam dan uji beda rata-rata umur bibit berpengaruh pada tinggi tanaman 21, 28 dan 35 HST, jumlah anakan 21, 28, 35 dan 42 HST, jumlah daun 14, 28 dan 42 HST, umur muncul malai, umur panen, biji per malai, berat basah dan berat kering. Namun tidak berpengaruh pada tinggi tanaman 14 dan 42 
HST, jumlah daun 21 dan 35 HST, anakan produktif, banyak malai, panjang malai dan berat 100 biji padi.

Hasil analisis ragam dan uji beda rata-rata pada Tabel 4 dan 5 menunjukan bahwa perlakuan umur bibit $b_{1}$ (umur bibit 30) dan $b_{2}$ (umur bibit 25) menunjukan hasil lebih baik dibandingkan dengan umur bibit yang lebih muda pada komponen tinggi tanaman 21, 28 dan 42 HST, jumlah anakan pada jumlah anakan 28 dan 35 HST, ratarata jumlah daun 14 HST dan umur muncul malai. Menurut Syaiful dan Sitawati (2019) perlakuan umur bibit 25 hari rata-rata jumlah daun tertingi hal ini disebabkan karena umur bibit mempengaruhi proses fotosintesis dan penyerapan nutrisi oleh akar tanaman. Pada umur bibit 25 hari menghasilkan kondisi tanaman yang lebih ideal saat akan pindah tanam ke modul tanam sehingga menjadikan tanaman mampu melakukan proses fotosintesis secara optimal, selain itu kondisi akar yang tidak terganggu dapat menyebabkan tanaman mampu menyerap nutrisi secara maksimal sehingga pertumbuhan menjadi lebih cepat. Pada umur bibit yang terlalu muda belum mampu menghasilkan pertumbuhan tanaman yang maksimal dikarenakan ketidakmampuan dalam mengatasi kondisi lingkungan serta penyerapan nutrisi yang diberikan dan belum optimal.

Tabel 4. Hasil uji beda rata-rata umur bibit terhadap tinggi tanaman 21, 28 dan 35 HST, jumlah daun 14, 28 dan 42 HST

\begin{tabular}{ccccccc}
\hline $\begin{array}{c}\text { Umur } \\
\text { bibit }\end{array}$ & $\begin{array}{c}\text { Tinggi } \\
\text { tanaman } \\
21 \text { HST }(\mathrm{cm})\end{array}$ & $\begin{array}{c}\text { Tinggi } \\
\text { tanaman } \\
28 \text { HST }(\mathrm{cm})\end{array}$ & $\begin{array}{c}\text { Tinggi } \\
\text { tanaman } \\
35 \text { HST }(\mathrm{cm})\end{array}$ & $\begin{array}{c}\text { Jumlah daun } \\
\text { 14 HST } \\
\text { (helai) }\end{array}$ & $\begin{array}{c}\text { Jumlah daun } \\
28 \text { HST } \\
\text { (helai) }\end{array}$ & $\begin{array}{c}\text { Jumlah daun } \\
42 \mathrm{HST} \\
\text { (helai) }\end{array}$ \\
\hline $\mathrm{b}_{1}$ & $51,30^{\mathrm{c}}$ & $65,20^{\mathrm{d}}$ & $78,94^{\mathrm{d}}$ & $34,58^{\mathrm{ab}}$ & $95,46^{\mathrm{ab}}$ & $168,79^{\mathrm{b}}$ \\
$\mathrm{b}_{2}$ & $52,25^{\mathrm{c}}$ & $64,60^{\mathrm{d}}$ & $76,08^{\mathrm{c}}$ & $36,37^{\mathrm{b}}$ & $87,79^{\mathrm{ab}}$ & $129,08^{\mathrm{a}}$ \\
$\mathrm{b}_{3}$ & $43,70^{\mathrm{b}}$ & $59,70^{\mathrm{c}}$ & $68,94^{\mathrm{b}}$ & $28,92^{\mathrm{ab}}$ & $80,54^{\mathrm{ab}}$ & $136,54^{\mathrm{ab}}$ \\
$\mathrm{b}_{4}$ & $40,46^{\mathrm{ab}}$ & $55,73^{\mathrm{b}}$ & $63,81^{\mathrm{ab}}$ & $24,21^{\mathrm{ab}}$ & $63,92^{\mathrm{a}}$ & $129,67^{\mathrm{ab}}$ \\
$\mathrm{b}_{5}$ & $36,71^{\mathrm{a}}$ & $47,48^{\mathrm{a}}$ & $56,85^{\mathrm{a}}$ & $21^{\mathrm{a}}$ & $55^{\mathrm{a}}$ & $126,21^{\mathrm{ab}}$ \\
\hline
\end{tabular}

Keterangan : Nilai rata-rata yang dikuti huruf yang sama pada kolom yang sama menunjukan perlakuan tersebut tidak berbeda berdasarkan uji DMRT pada taraf $5 \%$.

Tabel 5. Hasil uji beda rata-rata umur bibit terhadap jumlah anakan 21, 28, 35 dan 42 HST

\begin{tabular}{ccccc}
\hline $\begin{array}{c}\text { Umur } \\
\text { bibit }\end{array}$ & $\begin{array}{c}\text { Jumlah anakan } \\
21 \text { HST (anakan) }\end{array}$ & $\begin{array}{c}\text { Jumlah anakan } \\
28 \text { HST (anakan) }\end{array}$ & $\begin{array}{c}\text { Jumlah anakan } \\
\text { 35 HST (anakan) }\end{array}$ & $\begin{array}{c}\text { Jumlah anakan } \\
42 \text { HST (anakan) }\end{array}$ \\
\hline $\mathrm{b}_{1}$ & $12,42^{\mathrm{c}}$ & $13,42^{\mathrm{b}}$ & $23,71^{\mathrm{b}}$ & $23,33^{\mathrm{b}}$ \\
$\mathrm{b}_{2}$ & $10,04^{\mathrm{bc}}$ & $12,92^{\mathrm{b}}$ & $22,08^{\mathrm{b}}$ & $16,33^{\mathrm{a}}$ \\
$\mathrm{b}_{3}$ & $8,54^{\mathrm{b}}$ & $10,75^{\mathrm{ab}}$ & $18,38 \mathrm{a}^{\mathrm{ab}}$ & $15,87^{\mathrm{ab}}$ \\
$\mathrm{b}_{4}$ & $6,79^{\mathrm{ab}}$ & $9,00^{\mathrm{a}}$ & $17,38 \mathrm{a}^{\mathrm{ab}}$ & $16,96^{\mathrm{ab}}$ \\
$\mathrm{b}_{5}$ & $4,70^{\mathrm{a}}$ & $7,50^{\mathrm{a}}$ & $13,58^{\mathrm{a}}$ & $18,46^{\mathrm{ab}}$ \\
\hline
\end{tabular}

Keterangan : Nilai rata-rata yang dikuti huruf yang sama pada kolom yang sama menunjukan perlakuan tersebut tidak berbeda berdasarkan uji DMRT pada taraf $5 \%$.

Pada Tabel 6, umur bibit berpengaruh sangat nyata pada muncul malai dan umur panen. Pada muncul malai perlakuan $b_{1}$ (umur bibit 30 hari) menghasilkan muncul malai tercepat namun tidak berbeda dengan $b_{2}, b_{3}$ dan $b_{4}$ tetapi berbeda dengan $b_{5}$. Pada umur panen perlakuan $b_{1}$ (umur bibit 30 hari) menghasilkan panen tercepat tidak berbeda dengan $b_{2}$. Hal ini diduga karena umur bibit 
tua sudah memasuki fase vegatatif yang lebih dahulu atau lama saat persemaian sehingga mempersingkat umur muncul malai dan umur panen. Hal ini sesuai dengan penelitian Burbey et. al., (2014) yang mana umur bibit lebih tua juga menghasilkan umur muncul malai dan panen lebih cepat dibandingkan dengan umur muda.

Perlakuan umur bibit tidak berpengaruh terhadap panjang malai dan banyak malai dihasilkan hal ini sejalan dengan penelitian Sution dan Serom (2019) dimana perlakuan umur bibit tidak berpengaruh pada 2 peubah pengamatan ini.
Jumlah biji per malai dipengaruhi seacara tidak langsung oleh panjang malai padi, semakin panjang malai padi maka berpeluang menghasil jumlah biji per malai yang lebih banyak. Genotif dan jumlah populasi tanaman secara nyata memberikan pengaruh pada panjang dan banyak malai (Sutaryo et. al., 2014). Pada biji per malai perlakuan umur bibit berpengaruh nyata dimana perlakuan $\mathrm{u}_{1}$ (umur bibit 30 hari) menghasilkan biji per malai terbanyak, perlakuan $\mathrm{u}_{5}$ (umur bibit 10 hari) menghasilkan biji per malai paling sedikit.

Tabel 6. Hasil uji beda rata-rata umur bibit terhadap umur muncul malai, umur panen, biji per malai, berat basah dan berat kering

\begin{tabular}{cccccc}
\hline $\begin{array}{c}\text { Umur } \\
\text { bibit }\end{array}$ & $\begin{array}{c}\text { Umur muncul } \\
\text { malai (HST) }\end{array}$ & $\begin{array}{c}\text { Umur panen } \\
(\text { HST) }\end{array}$ & $\begin{array}{c}\text { Biji per malai } \\
(\mathrm{biji})\end{array}$ & Berat basah (g) & Berat kering (g) \\
\hline $\mathrm{b}_{1}$ & $55,13^{\mathrm{b}}$ & $79,5^{\mathrm{bc}}$ & $92,50^{\mathrm{b}}$ & $54,67^{\mathrm{c}}$ & $44,75^{\mathrm{b}}$ \\
$\mathrm{b}_{2}$ & $56,96^{\mathrm{ab}}$ & $79^{\mathrm{c}}$ & $88,92^{\mathrm{b}}$ & $47,36^{\mathrm{bc}}$ & $39,55^{\mathrm{b}}$ \\
$\mathrm{b}_{3}$ & $57,75^{\mathrm{ab}}$ & $82,33^{\mathrm{b}}$ & $85,21^{\mathrm{b}}$ & $41,04^{\mathrm{abc}}$ & $32,62^{\mathrm{ab}}$ \\
$\mathrm{b}_{4}$ & $59,79^{\mathrm{ab}}$ & $83,33^{\mathrm{b}}$ & $76,97^{\mathrm{a}}$ & $37,08^{\mathrm{ab}}$ & $30,25^{\mathrm{ab}}$ \\
$\mathrm{b}_{5}$ & $61,17^{\mathrm{a}}$ & $88,67^{\mathrm{a}}$ & $72,03^{\mathrm{a}}$ & $28,46^{\mathrm{a}}$ & $23,83^{\mathrm{a}}$ \\
\hline
\end{tabular}

Keterangan : Nilai rata-rata yang dikuti huruf yang sama pada kolom yang sama menunjukan perlakuan tersebut tidak berbeda berdasarkan uji DMRT pada taraf $5 \%$.

Wibowo (2010) menyatakan bahwa jumlah gabah atau biji permalai ditentukan oleh banyaknya jumlah anakan produktif, dan umur pembungaan lebih awal, dimana penyerbukan akan berhasil dan menghasilkan biji per malai yang lebih banyak. Hal ini sesuai dengan hasil penelitian Napisah dan Rina (2014) dimana perlakuan umur bibit 10 hari juga menghasilkan biji per malai paling sedikit. Burbey et. al., (2014) menyatakan perlakuan umur bibit lebih tua dapat memproduksi biji per malai lebih banyak dibandingkan dengan penggunaan bibit yang lebih muda.

Pada Tabel 6, berat basah pelakuan $\mathrm{b}_{1}$ (umur bibit 30 hari) menghasilkan berat basah terberat tetapi tidak berbeda dengan perlakuan $b_{2}$ dan $b_{3}$ tetapi berberbeda dengan $\mathrm{b}_{4}$ dan $\mathrm{b}_{5}$. Pada berat kering perlakuan $\mathrm{b}_{1}$ (umur bibit 30 hari) menghasilkan berat basah terberat tetapi tidak berbeda dengan perlakuan $b_{2}, b_{3}$ dan $b_{4}$ tetapi berberbeda dengan $b_{5}$. Hal ini sejalan dengan penelitian Khakim (2015) dimana perlakuan umur bibit 10 hari juga menghasilkan berat padi yang lebih ringan dibandingkan dengan umur 15 , 20 dan 25 hari. Bobot kering bagian atas yang lebih tinggi menandakan pertumbuhan tanaman yang optimal. Hasil gabah per rumpun yang dihasilkan akan maksimal jika bobot kering yang dihasilkan besar. Hal ini dikarenakan bobot kering yang besar juga akan menghasilkan distribusi asimilat yang semakin besar pada saat pengisian gabah produktif.

Hasil analisis ragam dan uji beda rata-rata pada Tabel 6, berat 100 biji tidak berpengaruh pada perlakuan umur bibit hal ini karena berat persatuan biji lebih di pengaruhi oleh sifat genetik dari varietas 
bukan dari perlakuan umur bibit. Berdasarkan deskripsi Varietas Ciherang dan Mekongga mampu menghasilkan berat 28 g per 1000 biji, Cisokan menghasilkan berat $22 \mathrm{~g}$ per 1000 biji (Suprihatno et. al., 2009). Berat 100 biji ditentukan oleh besar kecilnya ukuran biji dimana hal ini ditentukan oleh sifat bawaan bukan dari perlakuan maupun respon lingkungan. Hal ini sesuai dengan penelitian Anggraini et. al., (2013) perlakuan umur bibit juga tidak menunjukan adanya pengaruh pada berat 1000 biji padi.

\section{KESIMPULAN}

Dari hasil penelitian dapat disimpulkan interaksi terbaik dihasilkan oleh perlakuan $\mathrm{v}_{2} \mathrm{~b}_{1}$ (Cisokan Putih umur bibit 30 hari), perlakuan tunggal varietas $\mathrm{v}_{2}$ (Cisokan Putih) merupakan varietas padi adaptif terbaik dan perlakuan $b_{1}$ (umur bibit 30 hari) menghasilkan perlakuan umur bibit terbaik.

\section{UCAPAN TERIMAKASIH}

Penelitian ini dibiayai oleh Direktorat Pembelajaran dan Kemahasiswaan; Direktorat Jendral Pendidikan Tinggi, Riset dan Teknologi; Kementerian Pendidikan, Kebudayaan, Riset dan Teknologi melalui Program Kreativitas Mahasiswa (PKM) dengan Nomor Kontrak 81/LL/KM/2021 Tanggal 24 Mei 2021

\section{DAFTAR PUSTAKA}

Anggraini, F., A. Suryanto dan A. Nurul. (2013). Sistem Tanam dan Umur Tanaman Padi Sawah (Oryza sativa L.) Varietas Inpari 13. Jurnal Produksi Tanaman. 1(2): 52-60.

srraudeau, M. A dan B. S Vergara. (1992) Pedoman Budidaya Padi Gogo. BPTP. Bogor

Ar-Riza, I dan Y. Inan (2003). Optimalisasi pemanfaatan lahan rawa untuk peningkatan produksi padi. Prosiding seminar nasional inovasi teknologi sumberdaya tanah dan iklim pusat penelitian dan pengembangan pertanian. Bogor.

BPS Hulu Sungai Utara. (2020). Hulu Sungai Utara dalam Angka 2021. Badan Pusat Statistik Hulu Sungai Utara.

BPS Hulu Sungai Utara. (2021). Hulu Sungai Utara dalam Angka 2020. Badan Pusat Statistik Hulu Sungai Utara.

BPS Indonesia. (2020). Statistik Indonesia 2020. Badan Pusat Statistik Indonesia.

Burbey, Syahrial A., dan Nieldalina. (2014). Pengaruh umur bibit dan jumlah bibit pada padi sawah varietas umur genjah dan sangat genjah. URL : https://sumbar.litbang.pertanian.go.id . Diakses tanggal 2 September 2021.

Darsani, Y. R. dan A. Hairani. (2020). Preferensi Petani terhadap Keragaan Padi. Balai Penelitian Pertanian Lahan Rawa. 09(01): 22-32.

Guswara, A. dan Samaullah, M.Y. (2008). Penampilan beberapa varietas unggul baru pada sistem pengelolaan tanaman dan sumberdaya terpadu di lahan sawah irigasi. Seminar Nasional Padi. Hal 629-636.

Guswara, A. dan Samaullah, M.Y. (2008). Penampilan beberapa varietas unggul baru pada sistem pengelolaan tanaman dan sumberdaya terpadu di lahan sawah irigasi. Seminar Nasional Padi. Hal 629-636.

Hatta, M., M. Noor dan Sulakhudin. (2018). Peningkatan Produktivitas Padi di 
Lahan di Kalimantan Barat. Jurnal Pengkajian dan Pengembangan Teknologi Pertanian. 21(2):101-112.

Herlinda, S. (2019). Pengembangan Teknologi Budidaya Tanaman Adaptif Di Rawa Lebak Sumatera Selatan Berbasis Kebutuhan Petani. Prosiding Seminar Nasional Lahan Suboptimal :20-30.

Ihsan, N. (2012). Mengenal fase pertumbuhan padi. URL : https://ceritanurmanadi.wordpress.co m. Diakses pada 8 September 2021.

Khakim, M., S.H. Pratiwi dan N. Basuki. (2015). Pengaruh Umur Bibit dan Jarak Tanam terhadap Pertumbuhan dan Hasil Padi ( Oryza sativa L.) dengan Pola Tanam Sri. Jurnal Agroteknologi

Merdeka Pasuruan.1(1):1-9.

Marlina, Setyono dan Y. Mulyaningsih. (2017). Pengaruh Umur Bibit dan Jumlah Bibit terhadap Pertumbuhan dan Hasil Panen Padi Sawah (Oryza sativa L.). Jurnal Pertanian. 8(1) :26-35.

Maulidiya, L. (2015). Studi karakteristik pertumbuhan empat varietas padi (Oryza sativa L.) pada tiga ketinggian tempat berbeda. Skripsi. Universitas Jember

Muyassir. (2012). Efek Jarak Tanam, Umur dan Jumlah Bibit terhadap Hasil Padi Sawah (Oryza sativa L.). Jurnal Manajemen Sumberdaya Lahan. 1(2):207-212.

Napisah, K., dan Rina D., N. (2014). Pengaruh umur bibit terhadap produktivitas padi varietas Inpari 17. Prosiding Seminar Nasional Inovasi
Teknologi Pertanian Spesifik Lokasi. Banjarbaru.

Porong, V. J. (2012). Perbedaan Umur Bibit terhadap Pertumbuhan dan Produksi Padi sawah (Oryza sativa L). EUGENIA. 18(1):35-38.

Rachmawati, D. dan Retnaningrum, E. (2013). Pengaruh tinggi dan lama penggenangan terhadap pertumbuhan padi kultivar Sintanur dan dinamika populasi rhizobakteri pemfiksasi nitrogen non simbiosis. Bionatura. 15(2): $117-125$

Rahmawati, D. (2002). Studi pertumbuhan, potensi hasil viabilitas benih tujuh genotif padi gogo asal Kalimantan timur terhadap cekaman aluminium. IPB. Bogor.

Sari, W. M., Bayu, E. dan Ilyas, S. (2013). Karakter Vegetatif dan Generatif Beberapa Varietas Padi (Oryza $\begin{array}{lll}\text { sativa } & \text { L.) } & \text { Toleran }\end{array}$ Aluminium. Jurnal Agroekoteknologi Universitas Sumatera Utara. 1 (4): 1425-1438 .

Sitinjak, H. dan Idwar. (2015). Respon berbagai varietas padi sawah yang ditanam dengan pendekatan teknik budidaya jajar legowo dan sistem tegel. Jom Faperta. 2(2):1-15

Sulaiman, A,. K. Subagyono, T. Alihamsyah, M. Noor, Hermanto, A. Muharram, I.G.M. Subiksa, dan I.W.Suwastika. (2018). Membangkitkan Lahan Rawa, Membangun Lumbung Pangan Indonesia. Edisi 1. IAARD PRESS. Jakarta.

Suprihatno, B. A. A. Dradjat, Satoto, B. S.E., I. N. Widiarta, A. Setyono, S.D. Indrasari, O. S.Lesmana dan 
H.Sembiring. (2009). Deskripsi Varietas Padi. Balai Besar Penelitian Padi Subang.

Sution dan Serom. (2019). Pengaruh umur bibit dan jumlah bibit terhadap produktivitas padi sawah. Jurnal Pertanian Agros. 21(1): 100-107.

Syahputra, F dan I. Y. Inan. (2019). Prospek Lahan Sawah Lebak Untuk Pertanian Berkelanjutan Di Kabupaten Banyuasin Provinsi Sumatera Selatan. Indonesian Jurnal of Socio Economic. 1(2):109-114.

Syaiful, A. Sitawati, S. (2019). Pengaruh Umur Bibit pada Pertumbuhan dan
Hasil Tanaman Kailan (Brassica oleraceae) Sistem Ratun Secara Hidroponik NFT (Nutrient Film Technique). Jurnal Produksi Tanaman. 7(9): 1742-1751.

Waluyo dan Suparwoto. (2019). Inpari sebagai Varietas Padi Alternatif di Lahan Rawa Lebak Provinsi Sumatera Selatan. JURNAL ILMIAH AGROUST. 1(1):91-105.

Wibowo, P. (2010). Pertumbuhan dan produktivitas galur harapan padi hibrida didesa ketaon kecamatan banyudono boyolagi. Skripsi. Universitas Sebelas Maret . 